University of Miami Law School University of Miami School of Law Institutional Repository

1999

\title{
Integrating International Law Into the First-Year Property Course
}

Stephen J. Schnably

University of Miami School of Law, schnably@law.miami.edu

Follow this and additional works at: https://repository.law.miami.edu/fac_articles

Part of the Legal Education Commons

Recommended Citation

Stephen J. Schnably, Integrating International Law Into the First-Year Property Course, 93 Am. Soc'y Int'l L. Proc. 359 (1999).

This Article is brought to you for free and open access by the Faculty and Deans at University of Miami School of Law Institutional Repository. It has been accepted for inclusion in Articles by an authorized administrator of University of Miami School of Law Institutional Repository. For more information, please contact library@law.miami.edu. 
I use the case to show that a constitutional system concerns the expressions of a nation's selfunderstanding, and to make some points, which I do not defend strongly, about the German constitutional self-understanding as emerging from socialism, Catholic social thought and the experience of the Hitler era. Again, I think that students consider the use of the German material a bit peculiar, but I find it a helpful way to introduce discussion into U.S. constitutional selfunderstanding.

In conclusion, I do not want to offer what I have done as gospel. I am not even sure it works pedagogically any better than anything else. I have tried to show how one teacher attempts to use international human rights and comparative material in a basic course. My guess is that more of this is going to happen in the next decade, and that we will have a better sense in a few years about what the best ways to do it.

\section{INTEgRating INTERNational LAW INTO THE FIRST-Year Property COURSE}

$$
\text { by Stephen J. Schnably* }
$$

International law is most easily integrated into courses on practice areas that have become globalized (e.g., securities law) or for which there are clear-cut parallels (e.g., constitutional law and criminal law). But it can also be integrated into courses that fit neither criterion. Property is good example. Except for takings law, there are few obvious points of comparison, and real estate practice is largely domestic. Still, international law can enrich property in many ways, particularly where it is taught as a first-year course with an emphasis on legal reasoning.

Exposure to international law can help deepen students' appreciation of recurring issues in property. The law of servitudes asks how obligations under a regime that binds both the original parties and their successors can be terminated in light of unanticipated developments; the fundamental change of circumstances doctrine in the law of treaties asks a similar question, though in a very different context. A study of prescriptive acquisition of territory can enhance discussions of adverse possession, at the very least by making the concept seem less bizarre. In landlord-tenant law, the seeming futility of the implied warranty of habitability - few low-income tenants can afford lawyers-can make the reforms appear meaningless. Students' ability to grapple with this problem may well be enhanced by reviewing some of the rich literature analyzing the ways in which international law, with all its problems of enforceability, is still "law."

Inevitably, the aim is less to teach students international or foreign law than to enrich their understanding of property. But exposure to other legal systems besides state and federal law early in the curriculum can prove a useful means of building on the considerable interest in international matters that most students bring to law school.

\section{INTERNATIONALISM IN LEGAL EDUCATION: THE UNITED KINGDOM EXPERIENCE}

\section{by John Linarelli**}

The legal academy in the United Kingdom tends to be much more integrated into the general university structure. Student populations can be fairly international, particularly since some countries, such as Malaysia, consider the LL.B to be a qualifying law degree (the LL.B is an undergraduate degree). Postgraduate programs (e.g., the LL.M) and research postgraduate programs (the M.Phil and Ph.D) tend to have significant concentrations of European and international students.

It is difficult to exaggerate the effect of European integration and harmonization and European legal and institutional regimes on legal education in the United Kingdom. Law schools

\footnotetext{
- Professor, University of Miami School of Law, Coral Gables, FL.

- Lecturer in Law, University of Wales, Aberystwyth, United Kingdom.
} 